\title{
ANALYSIS OF DETERMINANT PERFORMANCE OF AGRICULTURAL EXTENSION AGENTS IN LEBAK DISTRICT, BANTEN PROVINCE OF INDONESIA
}

\author{
Herpriyana Martin, Student \\ Graduate Program, Sebelas Maret University, Indonesia \\ Suwarto, Anantanyu Sapja, Teaching Staff \\ Sebelas Maret University, Indonesia \\ *E-mail: martin.herpriyana@gmail.com
}

\begin{abstract}
The purpose of this study was to find out the determinants of the performance of agricultural extension agents in Lebak District and to analyze the determinants of the performance of Agricultural Extension agents in Lebak District. Determination of the research location was deliberately chosen purpose sampling based on certain considerations. The population unit in this study was 117 agricultural extension agents in Lebak District. The sampling technique used is census. The research variables included the characteristics of the agricultural extension agents (X1), competency of agricultural extension agents (X2), training (X3), and the performance of the agricultural extension agents $(Y)$. Data analysis techniques include descriptive statistical analysis to describe research data, path analysis to predict the effect of independent variables on the dependent variable, and to determine the direct and indirect effects of variables. The results of the descriptive statistical analysis in general the performance of agricultural extension agents in Lebak District are in the high category. This is indicated by the high performance of agricultural extension agents in two sub-variables, namely: extension planning sub-variables, and evaluation and reporting sub-variables. The performance aspects of agricultural extension agents are in the low category, namely: the implementation of agricultural extension agents' activities. The results of path analysis show that the characteristics of agricultural extension agents, competency of agricultural extension agents, and training have an effect on the performance of agricultural extension agents together at 64.2 percent. The most influential factor on the performance of agricultural extension agents is training.
\end{abstract}

\section{KEY WORDS}

Agriculture, extension, performance, characteristics, competency, training.

The government is obliged to organize agricultural, fisheries and forestry counseling. This shows that agricultural extension has a strategic role in development in Indonesia. Indonesia has long been known as an agricultural country. This is because Indonesia has a land area and agro-climate which is very potential to be developed as an agricultural business. Based on agricultural land statistics (Ministry of Agriculture, 2017) in 2016 there were around $36,764,318.50 \mathrm{Ha}$ which is the area of agricultural land in Indonesia. The population aged 15 years and over whom worked in the agricultural sector in August 2016 amounted to $37,770,165$ workers, which means around $31.90 \%$ of the total workforce of $118,411,973$ workers (BPS, 2017).

Agricultural development is very much determined by human resources in it. If human resources have high motivation, creativity and are able to develop innovation, then agricultural development can certainly be better. One of the human resources that plays a role in implementing government programs in efforts to develop agriculture is agricultural extension agents.

The agricultural extension agents' performance can show the extent of the agricultural extension agents' competence in carrying out tasks such as providing information about cultivation techniques, government policies, access to markets and capital, and other 
information needed by farmers. The performance of agricultural extension agents can be a reference for the government in determining policies including the provision of funds for the development of the agricultural sector as well as for increasing the competence of agricultural extension agents. One of the challenges faced by agricultural extension in Lebak District is the number of extension agents who are still far from the ideality of one village of one agricultural extension agents, namely from 345 villages and urban villages, only 128 extension agents who assist farmers. According to Gibson (1996), there are three factors that influence individual performance, namely: individual, psychological and organizational factors. Individual factors that influence individual performance, namely: ability, skills, family background, work experience, social level and demography. Psychological factors, namely: perception, role, attitude, personality, motivation and job satisfaction. Organizational factors, namely: organizational structure, job design, leadership and reward systems. Hickerson and Middleton (1975), stated that a person's performance is determined by the ability of the three behavioral aspects, namely cognitive, affective and psychomotor. As long as there is a gap between the performance of the officer and the performance demanded by his position, the officer cannot perform well in completing his main tasks.

The purpose of this study was to determine the level of performance of agricultural extension agents in Lebak District and to analyze the factors that influence the performance of Agricultural Extension agents in Lebak District. In this study an assessment of the level of performance $(\mathrm{Y})$ was carried out and an analysis of the determinants or factors influencing the performance of agricultural extension agents including the characteristics of agricultural extension agents (X1), competency of agricultural extension agents (X2), and training (X3).

\section{METHODS OF RESEARCH}

This type of research is survey research. Determination of the research location was deliberately chosen "purpose sampling" based on certain considerations. The population units in this study were 117 agricultural extension agents PNS, THL-TBPP, and TKK in Lebak District. The respondents' taking technique used was census, so the respondents in this study were all population units. Lebak District was chosen as a research site because Lebak District is one of the Regencies which is included in the criteria of underdeveloped areas in Banten Province which is close to the capital city of Indonesia, namely DKI Jakarta. Because of that status, the local government tried to get Lebak District out of the predicate of a disadvantaged region. Government efforts rely on the agricultural sector because agriculture is the highest economic support sector of Lebak District, especially in terms of employment and community income. The ease of access to big cities such as Jakarta, Bogor, Serang, Tangerang, and Cilegon where Merak Harbor is located is a distinct advantage for Lebak District which is recorded as the region that has the most agricultural workers in Banten Province. The independent variables in this study were the characteristics of agricultural extension agents which included age, period of work, use of the media, availability of facilities and infrastructure, and the level of active community participation; competency of agricultural extension agents which include managing extension activities, the ability to apply adult learning principles, communication skills, and collaboration skills; training that includes training suitability, length of training, and number of training.

The dependent variable in this study is the performance of agricultural extension agents which includes extension planning, implementation of extension activities, and evaluation and reporting. Data collection techniques in this study are interviews, observation, and recording. The data analysis method used in this study is validity test using product moments Pearson, reliability test by looking at Cronbach's alpha coefficient, descriptive statistical analysis, and then analysis of research data using path analysis.

\section{RESULTS AND DISCUSSION}

The results of the study with descriptive statistical analysis techniques in general the performance of agricultural extension agents $(Y)$ in Lebak District are in the high category of 
$55.6 \%$. The sub-variables of the agricultural extension agents performance are two subvariables in the high criteria which are at the median value of 3 (three) and one sub-variable in the low criterion which is at the median value of 2 (two). Sub-variables that are at the median value of 3 (three), namely: extension planning sub-variables as much as $55.6 \%$ of respondents included in the high criteria and evaluation and reporting sub-variables at $40.2 .7 \%$ of respondents are at high criteria. The sub-variables that are at the median value of 2 (two) are sub-variables for the implementation of extension activities at $47.9 \%$ of respondents are in the low criteria. This shows that most respondents have good performance in extension planning, implementation of extension activities, as well as evaluation and reporting.

The factors that influence the performance of extension agents are in the high category. This is indicated by the characteristics of agricultural extension agents (X1) in the high category $(53.00 \%)$, competency of agricultural extension agents (X2) in the high category (64.00\%), and training (X2) in the high category $(77.7 \%)$.

The results of simultaneous agricultural extension agents performance analysis influenced by the characteristics of agricultural extension agents, competency of agricultural extension agents, and training on the performance of agricultural extension agents are presented in the structural equation $Y=\rho Y X 1+\rho Y X 2+\rho Y X 3+\varepsilon$. To see the influence of characteristics of agricultural extension agents, competency of agricultural extension agents, and training on performance, then SPSS 25 was calculated to obtain R2 (R square). Based on calculations using SPSS the results in table 1 and table 2 are as follows:

Table 1 - List of Model Y Test Calculation Results

\begin{tabular}{lllll}
\hline Description & $\mathrm{R}^{2}$ & $\mathrm{~F}$ & Sig. & $\alpha$ \\
\hline Model $\mathrm{Y}$ & 0,606 & 58,050 & 0,000 & 0,05 \\
\hline
\end{tabular}

Based on table 1 , the value of the $R$ square is 0.606 . This number states the value of the influence of the characteristics of agricultural extension agents, competency of agricultural extension agents, and training combined on performance, by calculating determinant coefficient $(K D)$ with the KD formula $=(R 2) \times 100 \%$ so that $K D=60.6 \%$.

Table 2 - Value of Path Coefficients and Correlation Coefficients

\begin{tabular}{lllll}
\hline No & Description & Path Coefficients $(\beta)$ & Correlation Coefficients $(r)$ & $(r-\beta)$ \\
\hline 1. & X1 with $Y$ & 0,120 & 0,232 & 0,112 \\
2. & X2 with $Y$ & 0,374 & $0,460^{* *}$ & 0,086 \\
3. & X3 with $Y$ & 0,621 & $0,655^{* *}$ & 0,034 \\
\hline
\end{tabular}

Based on table 2, we can enter the path coefficient in the model $Y$ and the error coefficient $(\varepsilon)$ can be determined by the formula $\varepsilon=\sqrt{1-R^{2}}$ so that the value $\varepsilon$ nilai $\varepsilon=\sqrt{1-0,606}=\sqrt{0,394}=0.628$. From the calculation results, the equation of the path test becomes $\mathrm{Y}=0.120 \mathrm{X} 1+0.374 \mathrm{X} 2+0.621 \mathrm{X} 3+0.628$. The value obtained by $60.6 \%$ means that the influence of the characteristics of agricultural extension agents, competency of agricultural extension agents, and training on performance is $60.6 \%$, while the remaining $39.4 \%$ is influenced by other factors that cannot be explained in this study.

To show the results of the analysis stating that the characteristics of agricultural extension agents, competency of agricultural extension agents, and training directly influence the performance is evidenced by the value of $\beta$ with $(r-\beta)$ provided that $\beta>(r-\beta)=$ independent variable has a direct effect (significant) and if $b<(r-\beta)=$ variable-free does not have a direct effect (not significant).

The results of the analysis in table 3 show that characteristics of agricultural extension agents directly influence performance, this is evidenced by the value of $\beta>(r-\beta)$ which is $0.120>0.112$. The value of the direct influence of the characteristics of agricultural extension agents on performance is indicated by the path coefficient value ( $\rho Y X 1)$. The path coefficient value $(\rho Y X 1)$ is equal to 0.120 which means that there is a significant direct effect of the 
characteristics of agricultural extension agents on performance of $1.44 \%(0.1202 \times 100 \%)$. Sub variables that have a direct effect on performance are the period of work and the use of the media. The period of work directly influences the performance as evidenced by the value of $\beta>(r-\beta)$ which is $0.122>0.080$. The value of the direct effect of period of work on performance is indicated by the path coefficient value $\rho Y X 1.2$ of 0.122 , which means that there is a significant direct effect on the period of work of the performance of $1.49 \%(0.1222$ $x 100 \%$ ). The research results of Bryan and Glenn (2004) show that work experience has a positive effect on new extension agents, while those who have worked longer will show the level of client satisfaction. The work experience of extension agents shows the skills in question in carrying out work, both in technical and planning terms. The availability of facilities and infrastructure directly influence the performance as evidenced by the value of $\beta>(r-\beta)$ which is $0.337>0.021$. The value of the direct effect of the availability of facilities and infrastructure on performance is indicated by the path coefficient value $\rho Y X 1.4$ of 0.337 , which means that there is a significant direct effect on the availability of facilities and infrastructure to the performance of $11.36 \%(0.3372 \times 100 \%)$. This is in line with the opinion of Mardikanto (2009) that efforts to change farming delivered by extension agents to farmers are very dependent on the availability of production facilities and equipment (new) in the form of quantity, quality and the right time. If this facility is available, the success of the extension agents will be achieved.

Table 3 - Analysis of Determinants of Extension Agents

\begin{tabular}{|c|c|c|c|c|c|}
\hline Sub Variable & r & $\beta$ & $(r-\beta)$ & $\begin{array}{l}\beta>(r-\beta) / \\
\beta<(r-\beta)\end{array}$ & Information \\
\hline Age (X1.1) & 0,136 & 0,030 & 0,106 & $0,030<0,106$ & not significant \\
\hline Period of work (X1.2) & 0,202 & 0,122 & 0,080 & $0,122>0,080$ & significant \\
\hline Use of the media (X1.3) & $-0,007$ & $-0,067$ & 0,060 & $-0,067<0,060$ & not significant \\
\hline Availability of facilities and infrastructure (X1.4) & 0,358 & 0,337 & 0,021 & $0,337>0,021$ & significant \\
\hline Level of active community participation(X1.5) & 0,211 & 0,010 & 0,201 & $0,010<0,201$ & not significant \\
\hline Managing extension activities (X2.1) & $-0,070$ & 0,089 & 0,019 & $-0,089<0,019$ & not significant \\
\hline Ability to apply adult learning principles (X2.2) & 0,229 & 0,164 & 0,065 & $0,164>0,065$ & significant \\
\hline Communication skills (X2.3) & 0,251 & 0,301 & $-0,050$ & $0,301>-0,050$ & significant \\
\hline Collaboration skills (X2.4) & $-0,171$ & $-0,294$ & 0,123 & $-0,294<0,123$ & not significant \\
\hline Training suitability (X3.1) & 0,453 & 0,303 & 0,015 & $0,303>0,015$ & significant \\
\hline Length of training (X3.2) & 0,422 & 0,221 & 0,201 & $0,221>0,201$ & significant \\
\hline Number of training (X3.3) & 0,286 & 0,128 & 0,158 & $0,128<0,158$ & not significant \\
\hline
\end{tabular}

Age sub-variables did not significantly influence the performance of agricultural extension agents. This is in accordance with Robbins (1996) that a person's age is closely related to performance; the reason that reinforces this expression is that a person's productivity will decline with age. Speed, dexterity, strength and coordination deteriorate with the passage of time. Tedious work and lack of intellectual stimulation will also reduce productivity. Sub-variables use of the media has no significant effect on the performance of agricultural extension agents. This condition can be caused because the implementation of extension is usually carried out in the field such as farmers' land and fields so that the use of media such as electronic media, print media, and visual media is not too often due to the condition of the location of the extension. The level of active community participation has no significant effect on the performance of agricultural extension agents. The performance of agricultural extension agents is said to be good if the existence and activities or programs that are conveyed always receive the support and active participation of the entire community. This is in line with the opinion of Sumardjo (2010) that if people have been willing to act towards improving the lives of themselves, their families and communities then it can be said that the people have participated in development. The level of active community participation has no significant effect on the performance of agricultural extension agents because of the low level of community participation.

The results of the analysis in table 3 show that the competency of agricultural extension agents directly influences the performance as evidenced by the value of $\beta>(r-\beta)$ which is $0.374>0.086$. The value of the direct influence of the competency of agricultural extension agents on performance is indicated by the path coefficient value ( $\rho Y X 2)$. The path 
coefficient value ( $\rho Y X 2$ ) is equal to 0.374 , which means that there is a significant direct influence of the competency of agricultural extension agents on performance of $13.99 \%$ $(0.3742 \times 100 \%)$. Sub-variables that directly influence performance are the ability to apply adult learning principles and communication skills. The ability to apply adult learning principles directly affects the performance as evidenced by the value of $\beta>(r-\beta)$ which is $0.164>0.065$. The value of the direct effect of the ability to apply adult learning principles to performance is indicated by the path coefficient value $\rho Y X 1.1$ of 0.164 , which means that there is a significant direct effect on the ability to apply adult learning principles to performance of $2.69 \%(0.1642 \times 100 \%)$. This is because extension agents have met the criteria conveyed by Sumardjo (1999) that competence involves methodical abilities and learning techniques/developing learning experiences to influence and change knowledge/insights, skills/actions and attitudes (interests) of extension goals, arouse learning needs, realize responsibility and target needs of extension.

Communication skills directly influence the performance as evidenced by the value of $\beta>(r-\beta)$, which is $0.301>-0.050$. The value of the direct effect of communication skills on performance is indicated by the path coefficient value $\rho Y X 1.1$ of 0.301 which means that there is a significant direct effect of communication skills on performance at $9.06 \%(0.3012 \mathrm{x}$ $100 \%$ ). This is in accordance with what Mujiburrahmad (2014) stated that extension activities are communication activities, as professional communicators agricultural extension agents must first know, master and explore information (messages) that will be conveyed to the target community. Extension agents must have extensive knowledge about development information, science, technology that will be delivered to the target community. This competency must be equipped with the ability of the methods, methods, and techniques to convey it so as to achieve maximum results. Extension agents should master the concept of communication and ways of communicating.

The sub-variable for the managing extension activities did not have a significant effect on the performance of agricultural extension agents because managing extension activities was more directed towards mere routines. Managing extension activities should be like what Mulyasa (2002) said that competence is a combination of knowledge, attitudes and values, and skills reflected in the habit of thinking and acting. Sub-variables collaboration skills has no significant effect on the performance of agricultural extension agents because extension agents have not been able to do what Mardikanto (2009) said that communication in extension is a tool to cause changes in extension. In general, communication is defined as a process of delivering messages from the source to the recipient, in practice communication is not only limited to the message that has been delivered or received by the recipient of the message, but the recipient is expected to give a response to the source or sender for later communication continues.

The results of the analysis in table 3 show that training directly affects the performance of agricultural extension agents as evidenced by the value of $\beta>(r-\beta)$ which is $0.621>0.034$. The value of the direct effect of training on performance is indicated by the path coefficient value $(\rho Y X 3)$. The path coefficient value $(\rho Y X 3)$ is 0.621 which means that there is a significant direct effect of training on performance of $38.56 \%(0.6212 \times 100 \%)$. Sub-variables that have a direct effect on performance are the training suitability and the length of training. The training suitability directly affects the performance as evidenced by the value of $\beta>(r-\beta)$ which is $0.303>0.015$. The direct effect of training suitability on performance is indicated by the path coefficient value $\rho Y X 3.1$ of 0.303 , which means that there is a significant direct effect of training suitability on performance of $9.18 \%(0.3032 \times 100 \%)$. This shows that the training conducted by extension agents is in accordance with what was stated by Sikula in Sumantri (2000) that training is a short-term educational process that uses systematic and organized methods and procedures. The length of the training directly affects the performance as evidenced by the value of $\beta>(r-\beta)$ which is $0.221>0.201$. The amount of direct effect of training duration on performance is indicated by the path coefficient value $\rho Y X 3.2$ of 0.221 , which means that there is a significant direct effect on the duration of training on performance of $4.88 \%(0.2212 \times 100 \%)$. The sub-variable number of training did not significantly influence the performance of agricultural extension agents. This is because 
training is sometimes not carried out by training needs analysis to find out whether there is a training need and if there is indeed, what training needs are needed to fill the gaps, when it is not carried out, the training does not answer the description, extension agents were not able to do what Gomes (1995) said that training was every effort to improve work performance in a particular job that was his responsibility. Ideally, training should be designed to realize organizational goals, which at the same time also realize the goals of individual agents.

\section{CONCLUSION}

Based on the results of descriptive statistical analysis, a conclusion can be drawn, namely that in general the performance of agricultural extension agents $(Y)$ in Lebak District is in the high category of $55.6 \%$. The high performance of agricultural extension agents in two sub-variables, namely: extension planning sub-variables and evaluation and reporting sub-variables. Based on the results of the path test analysis showing the characteristics of the agricultural extension agents, competency of agricultural extension agents, and training have an effect on jointly on the performance of agricultural extension agents by $60.6 \%$. The most influential factor on the performance of agricultural extension agents was training at $38.56 \%$. Sub variables that have a significant effect on the performance of agricultural extension agents are period of work, availability of facilities and infrastructure, ability to apply adult learning principles, communication skills, training suitability, and length of training. Subvariables that did not significantly influence the performance of agricultural extension agents were age, use of the media, level of active community participation, managing extension activities, collaboration skills and the number of training.

\section{REFERENCES}

1. Badan Pusat Statistik. 2017. Keadaan Angkatan Kerja di Indonesia Agustus 2017. Jakarta: Badan Pusat Statistik.

2. Bryan, DT., Glenn, DI. 2004. Agent Performance and Customer Satisfaction. Jurnal of Extension. Number 6 Volume 42 Desember 2004.

3. Gibson, I. 1996. Organisasi and Manajemen. Jakarta: Erlangga.

4. Gomes, F.C. 1995. Manajemen Sumber Daya Manusia. Yogyakarta: Andi Offset.

5. Hickerson, F.J. and Middleton, John. 1975. Helping People Learn: A Module for Training Trainers. Honolulu-Hawai: East-West Comunnication Institut.

6. Kementerian Pertanian. 2017. Statistik Lahan Pertanian 2012-2016. Jakarta: Pusat Data and Sistem Informasi Pertanian. Sekretariat Jenderal Kementerian Pertanian.

7. Mardikanto, Totok. 2009. Sistem Penyuluhan Pertanian. Surakarta; Sebelas Maret University Press.

8. Mujiburrahmad. 2014. Kinerja Penyuluh Pertanian di Kabupaten Pidie Provinsi Aceh. Bogor: Institut Pertanian Bogor.

9. Mulyasa, 2002. Kurikulum Berbasis Kompetensi. Konsep, Karakteristik, and Implementasi. Bandung. Remaja Rosdakarya.

10. Robbins, Stephen. P. 1996. Perilaku Organisasi. Edisi bahasa Indonesia Jilid 1. Jakarta: Prenhallindo.

11. Sumantri, S. 2000. Pelatihan and Pengembangan Sumber Daya Manusia. Bandung: Fakultas Psikologi Unpad.

12. Sumardjo. 1999. Transformasi Model Penyuluhan Pertanian Menuju Pengembangan Kemandirian Petani (Kasus di Provinsi Jawa Barat). Bogor: Institut Pertanian Bogor.

13. 2010. Penyuluhan Menuju Pengembangan Kapital Manusia and Kapital Sosial Dalam Mewujudkan Kesejahteraan Rakyat. Orasi IImiah Guru Besar Dalam Rangka Dies Natalis IPB ke-47. Bogor. Institut Pertanian Bogor. 